Teologia i Moralność, volumen 16(2021), numer 1(29)

doi: 10.14746/TIM.2021.29.1.5

ORCID: 0000-0002-1041-9812

MONIKA OLIWA-CIESIELSKA

Uniwersytet im. Adama Mickiewicza w Poznaniu

Wydział Socjologii

\title{
Milczenie jako strategia komunikacyjna ludzi w kulturze ubóstwa
}

\section{Analiza wybranego materiału i podejście badawcze}

Celem niniejszego artykułu jest ukazanie problemów z komunikowaniem się osób żyjących w kulturze ubóstwa, które charakteryzują się przymusową izolacją z obszaru dyskursu i przyjmowaniem milczenia jako trwałej strategii interakcyjnej. Oscar Lewis, twórca koncepcji kultury ubóstwa wskazuje, że skrajnie biedni ludzie niezależnie od warunków kulturowo-społecznych charakteryzują się podobnymi cechami, m.in. dlatego, że podobne, trudne pod względem ekonomicznym warunki życia są podstawą powstawania podobnych problemów. Ludzie, będąc w skrajnej deprywacji, mają ograniczone możliwości działania, a to powoduje ujednolicenie funkcjonowania, skupionego głównie na przetrwaniu. Według Lewisa kultura ubóstwa to „pewien sposób życia szczególnie niezmienny i trwały, przekazywany z pokolenia na pokolenie na terenie poszczególnych rodzin. Kultura ubóstwa ma dla tych, którzy należą do jej kręgu, właściwe przepisane sposoby postępowania i wyróżniające społeczne i psychologiczne skutki” (Lewis 1964, 25).

Podjęta przeze mnie analiza ukazuje cechy dyskursu, który prowadzi do pogłębiania i utrwalania marginalnej pozycji ubogich wobec otoczenia społecznego i bliskich w rodzinie, którzy wymagają podporządkowania, demonstrując własną przewagę m.in. przemocą werbalną. Główne zagadnienia poruszane $\mathrm{w}$ artykule odnoszą się do strategii milczenia, która ma pełnić funkcje ochronne przed dotkliwymi relacjami. Jest to strategia będąca wynikiem dysfunkcji socjalizacyjnych, problemów z wyrażaniem emocji i uczuć, a także 
przyjmowaniem biernej postawy wobec doświadczanej agresji werbalnej. Pogłębiona analiza badanych źródeł pozwala wskazać, że porozumiewanie się z innymi, którzy współdoświadczają skrajnego ubóstwa, nacechowane jest przymusem milczenia i podporządkowania, co wbrew zamierzeniom powoduje i utrwala kolejne problemy.

Prezentowany artykuł jest częścią szeroko zarysowanej analizy funkcjonowania ludzi w kulturze ubóstwa, której wyniki zawarte są w pracy $W$ poszukiwaniu kultury ubóstwa (Oliwa-Ciesielska 2013). Głównymi źródłami analizy prezentowanej w tym artykule są prace O. Lewisa, które stanowią zapis jego badań empirycznych dotyczących autorskiej koncepcji kultury ubóstwa (1964; 1970; 1976; 2011a; 2011b). Kolejnym źródłem poddanym analizie są Pamiętniki bezrobotnych wydane w latach 30 . XX wieku, a także opublikowane w latach 2003-2006 (Pamiętniki bezrobotnych 1933; 1967a; 1967b; 2003a; 2003b; 2005a; 2005b; 2006).

Dobór źródeł podyktowany był przede wszystkim zamierzeniem prowadzenia jakościowej analizy materiału, który wytworzony był w różnym, znacznym dystansie czasowym; w odmiennym tle kulturowo-społecznym, ale jednocześnie był podobny pod względem konstrukcji. Poszukiwałam zatem materiału, który byłby bezpośrednim zapisem wypowiedzi ludzi, doświadczających skrajnego ubóstwa. Materiał taki daje szansę na analizę nie tylko tego, o czym mówi, ale także, w jaki sposób mówi - jak dany przekaz jest konstruowany, także pod względem językowym. Poszukiwaniu i włączeniu do badań w celowym doborze źródeł, odmiennych i spełniających te cechy przyświecało mi założenie Lewisa o istnieniu podobnie doświadczanego ubóstwa we wszystkich typach społeczeństw, niezależnie od czasu historycznego, a także o istnieniu wspólnych cech, charakteryzujących jednostki dotknięte biedą.

Analizowany przeze mnie materiał łącznie liczy ponad 5 tys. stron, zawiera wiele wątków, wśród których ważnym zagadnieniem są podjęte w artykule relacje społeczne osób ubogich i sposoby komunikacji z innymi. Ze względu na ich złożony charakter w prezentowanym artykule skupiam się głównie na jednym wyodrębnionym obszarze, który dotyczy milczenia, niepodejmowania dialogu, przymusu niewchodzenia w werbalne interakcje. Uwzględniając opowieści o dialogu i braku dialogu z innymi, wykorzystałam eksploracyjne studium przypadku (exploratory cases).

Zagadnienia dotyczące opowieści pozwalają za znaczące uznać to, co pozawerbalne - milczenie i ciszę. Jak pisze Kathy Charmaz, „Chwile ciszy mają bardzo szczególnie znaczenie jako dane w każdym badaniu, które jest związane z wyborami etycznymi, dylematami moralnymi i polityką społeczną. Cisza oznacza nieobecność, czasami brak świadomości lub nieumiejętność wyrażenia słów i uczuć" $(2009,736)$. Podjęta przeze mnie analiza materiałów zastanych nie mogła bezpośrednio „obserwować milczenia”, ale bogaty materiał 
pozwolił mi wyodrębnić ten problem ze sposobów opisywania go w różnych kontekstach i retrospektywnych przekazach. Pamiętanie własnych doświadczeń jest organizowane indywidualnie, ma charakter kontekstowy i sekwencyjny. Ta sekwencyjność w pewnej mierze ułatwiła wyodrębnienie z wielości wątków tych, które są skupione na analizowanej kategorii milczenia (Silvermann 2008, 83).

Prowadzoną analizę wpisałam w wymogi metody teorii ugruntowanej (w moim przypadku jako oznaczenia metody badań i konkretnego sposobu analizy). Jak wskazuje Krzysztof T. Konecki, metodologia teorii ugruntowanej zawiera jedną z najlepiej opracowanych strategii badań jakościowych, jest swoista, będąc konsekwencją założeń teoretycznych zawartych w paradygmacie interpretatywnym, w odniesieniu do symbolicznego interakcjonizmu $(2000,24)$. Metoda teorii ugruntowanej uznaje, że wszelkie teorie i wyjaśnienia na temat rzeczywistości danego problemu wyłaniają się w trakcie systematycznych badań z danych empirycznych, bezpośrednio odnoszących się do tej rzeczywistości. Dzięki tej metodzie nie tworzy się ,deklaratywnych stwierdzeń, a dyskutuje się tylko możliwości przyjęcia twierdzeń o danym i wydzielonym obszarze rzeczywistości społecznej” (Konecki 2000, 36). Jak mówią Barney G. Glaser i Anselm L. Strauss, ,rodzaj dowodów, jak i liczba przypadków nie mają tak zasadniczego znaczenia. Pojedynczy przypadek może wskazywać ogólną pojęciową kategorię lub własność, kilka dalszych przypadków może potwierdzić wskazówkę" $(2009,29)$.

Selekcjonując wybrane wątki w treści źródeł, skupiłam się na pogłębianiu analizy zagadnień związanych z interakcją i komunikacją - między rodzicami i dziećmi, między małżonkami, między samymi dziećmi. W ramach badań posłużyłam się także możliwą metodą permanentnej analizy porównawczej, która polega na „porównaniu z sobą różnych przypadków, zdarzeń, zjawisk, zachowań w celu ustalenia tego, co je wzajemnie wiąże, i określenia tego, co jest wspólne w różnych, zmiennych warunkach występowania badanych zjawisk" (Konecki 2000, 31). Takie wytyczne są potrzebne w sytuacji zamierzonej analizy kilku materiałów źródłowych, jakimi w moim przypadku były Pamiętni$k i$ oraz prace O. Lewisa. Wytyczne te pozwalają na poszukiwanie wspólnych cech w tematycznie zbieżnych materiałach wytwarzanych w różnym czasie. (Ze względu na ograniczenie treści w prezentowanym artykule nie zamieszczam charakterystyki zasad porównywania). W artykule zamieszczam cytaty z wypowiedzi, aby udostępnić charakterystyczne egzemplifikacje dające wgląd w materiały. Pozwoliły mi one ukazać pewne prawidłowości i wysuwać uogólnione wnioski (Rapley 2010, 221). 


\section{Milczenie jako główny obszar analizy}

Milczenie w języku polskim określa sytuację odmienną od zwykłego braku dźwięków, które może być ujmowane jako cisza. W literaturze analizującej niuanse dotyczące milczenia jest ono określane jako brak mowy, co nie jest równoznaczne z ciszą. Ciszę można uznać za brak dźwięków, a zatem także jako konsekwencję niemówienia (Osika 2016, 37). Samo niemówienie nie jest milczeniem. Jak wskazuje Dobrosław Kot, „Milczenie pozostaje w szczególnej relacji do mowy. Nie jest zwykłą nieobecnością mowy. Jest jej brakiem w przestrzeni, gdzie mowa może w ogóle się pojawić" $(2012,108)$. Milczenie jako niemówienie nie oznacza jedynie braku przekazu, braku słów, ale oznacza słowa niewypowiedziane - obrazowo mówiąc, takie które z jakiegoś powodu uwięzły wewnątrz tego, kto chciał coś wyrazić i z jakiegoś powodu tego nie uczynił.

Znamienne jest, że drugiego człowieka można poznać po tym, co mówi, ale także po tym, czego nie wypowiada, o czym milczy. Milczy się na jakiś temat, ale też przemilcza się to, co (nie) mogłoby, czy (nie) powinno być wypowiedziane. Znana sentencja Ludwiga Wittgensteina, część tego uwikłania oddaje w słowach „O czym nie można mówić, o tym trzeba milczeć” $(1997,83)$. Warto zaznaczyć, za wskazaniami Doroty Korwin-Piotrowskiej, że przemilczanie należy odróżnić od zatajania, „zatajanie polega na całkowitym usunięciu czegoś, celowym ukryciu, które nie prowadzi wcale na ślad pomijanych treści, jak to jest w przypadku przemilczeń" (2016, 124-125). Samo milczenie może być wymowne, jest wówczas jedną z form przekazu. Żeby jednak uznać je za niewyartykułowany przekaz, trzeba wiedzieć (odczuwać, przeczuwać), że dana osoba dysponuje przekazem, którego nie zakomunikowała w żaden sposób. Bez tej wiedzy milczenie można błędnie odebrać jedynie jako ciszę. Można powiedzieć, że o ile cisza jest warunkiem usłyszenia dźwięku wypowiedzi, o tyle milczenie jest warunkiem docierania do jej sensu. Chodzi w tym aspekcie także o zamilknięcie po to, aby nie tylko słuchać, ale też słyszeć i wysłuchać, stworzyć podstawowy warunek do dialogu. Milczenie może być otwarciem na innych, gotowością wsłuchania się w prowadzony dialog. Magdalena Szpunar podkreśla, że „Bez milczenia żaden dialog nie byłby możliwy, stanowi ono bowiem warunek słuchania" $(2020,266)$. Milczenie może jednak być demonstrowaniem postawy przeciwnej - zamknięciem na innych, ucieczką od relacji. Powody zarówno tego otwarcia, jak i zamknięcia mogą być bardzo rozbudowane (np. ochrona siebie, chęć zranienia innych brakiem dialogu, reakcja na ich wypowiedź), niezależnie od tego czy są one uświadamiane czy też nie.

Milczenie może mieć pozytywne i negatywne konteksty, a w ich ramach dokonują się kolejne zróżnicowania milczenia, wyodrębnienia go przed momentem ubrania czegoś w słowa, milczenia po ubraniu czegoś w słowa, a co 
jeszcze nie zostało wypowiedziane oraz milczenie po tym, co już wypowiedziane. Można to różnicować dalej na odmienne milczenie podmiotu, który konstruuje wypowiedzi, od milczenia odbiorcy, który konkretyzuje sens przekazu.

Milczenie może być też związane z niedopuszczeniem do mówienia, a nawet niepozwoleniem sobie na monolog. Dialog jest przeciwstawiany monologowi, który nie zakłada wymiany między rolami mówiącego i słuchającego, nie przewiduje też odwzajemniania (Macario i Rocchi 2011, 155). Dialog należy rozumieć jako szczególny rodzaj porozumiewania. Janusz Maj, odnosząc się do tej kwestii, mówi: „Dialog jako wydarzenie między bytami polega na tym, że wchodzą one w relacje między sobą, otwierają się na siebie, zachowując jednocześnie asymetryczność wobec siebie" $(2009,69)$. W metaforycznym przekazie milczenie charakteryzowane jest w opozycji do otwarcia: „Otwarte usta zatem, to możliwość mówienia i zarazem możliwość bycia z ludźmi, usta zamknięte to brak mówienia, ale także lojalne zachowywanie tajemnicy" (Pacławska 2010,36). W tej niemożności wydobywania z siebie słów zawarte są emocje skrajnie ubogich, którzy milczenie traktują jako ochronę przed spodziewanym, bolesnym doświadczeniem odrzucenia.

Milczenie jako kategoria poddana badaniu może być analizowane w różnych kontekstach. Jednym z nich jest wskazanie na milczenie w odniesieniu do coraz bardziej pożądanego i oczekiwanego sposobu reakcji, a nawet trwałej postawy wobec otaczającego jednostkę hałaśliwego świata. Milczenie wówczas, czasem zapowiadające niezgodę na funkcjonowanie wśród zgiełku i natłoku, jest wyborem jednostki, podejmowanym w celu ochrony siebie, nierzadko z głęboką wiarą w sens takiego działania, które ma skutkować niepogłębianiem chaosu we własnym życiu i w otaczającym świecie. Korzystanie z milczenia jako niewerbalnego składnika interakcji jest w wielu przypadkach intencjonalne, ma wywołać określone skutki. Jak wskazuje Kwiryna Handke „może ono służyć do: pytania, zaprzeczania, obiecywania, wyrażania oburzenia, ostrzegania, pogardzania, grożenia, znieważania, rozkazywania, protestowania, buntowania się, zachowania tajemnicy, wstydzenia się, celowego taktycznego postępowania, okazywania: bezradności, nieśmiałości, strachu, znużenia, braku zainteresowania, braku energii życiowej itd." (2008, 18).

Perspektywa w przyjętej przeze mnie analizie milczenia osób żyjących w skrajnym ubóstwie, ukazuje negatywny obraz, który określa milczenie jako przymus, a nie wybór jednostki. Skutkuje to brakiem dialogu czy choćby wymiany informacji, staje się ono udręką niepozwalającą na ukazywanie prawdy o sobie, na dzielenie się z innymi swoimi problemami. Ten przymus milczenia, a w konsekwencji przekonanie o byciu ignorowanym i niesłuchanym, jest doświadczeniem, które trwale charakteryzuje ludzi pogrążonych w skrajnym ubóstwie. Milczenie w ich sytuacji jest z jednej strony postawą wymuszaną przez innych, a z drugiej jest także obranym środkiem zaradczym, mają- 
cym chronić przed pogłębianiem problemów. Jest ono zatem przyjmowane jako strategia, która ostatecznie ugruntowuje i pogłębia wykluczenie i izolację. Dzieje się to niejednokrotnie w iluzorycznej zgodzie na milczenie, która w rzeczywistości jest raczej rezygnacją z nieskutecznego buntu przeciw byciu ignorowanym. Milczenie dla skrajnie ubogich nie oznacza w żadnej mierze braku problemów, jednak dla otoczenia społecznego oznacza skuteczne ich wyciszanie, wygodne przyzwolenie na niezauważanie ich. Wartość milczenia jest uwarunkowana tym, czym ono jest powodowane, a także - jak wskazuje Włodzimierz Zatorski - „zależy od tego czemu ono służy” $(2012,30)$.

Praktyka milczenia ubogich jest nie tylko stosowana wobec otoczenia społecznego, ale jest także praktyką wewnątrzgrupową, w sytuacji izolowania się od bliskich. Jest to najczęściej wynik obawy przed podjęciem dialogu, która dominuje nawet wtedy, gdy jest to wbrew własnemu interesowi, ponieważ mówienie o problemach mogłoby skutkować pomocą, współczuciem, zmianą stereotypów.

\section{Socjalizowanie dzieci do milczącego przeczekiwania problemów}

Milczenie jest częstą praktyką podejmowaną przez ludzi ubogich w relacjach społecznych. Do takiej postawy są oni socjalizowani, zwłaszcza jeśli doświadczają ubóstwa od czasu dzieciństwa, gdy ubóstwo jest doświadczeniem pokoleniowym. Milczenie dzieci w kulturze ubóstwa jest wymuszone przez dorosłych, którzy mając świadomość bezsilności wobec problemów, skłonni są nakazywać nierozmawianie o nich. Nie jest to tożsame z postawą obojętności, może być przejawem wstydu czy zażenowania z powodu niemocy działania, zaradzenia problemom. Takie odczucia trafnie oddaje wskazanie „Inny zagaduje mnie, prosi o pomoc. Ja nie potrafię mu pomóc, więc milczę. Wstydzę się tego, że nie mogę nic zrobić. [...] Bezradność jest więc wstydem «winy niezawinionej». Taki wstyd może wynikać z faktycznej bezradności w danej chwili człowiek nie dysponuje środkami, by zaradzić złu - albo też z bezradności fundamentalnej: człowiek wie, że nic nie da się zrobić; człowiek wie, że żadne słowo nie pomoże, żadne słowo nie uleczy, że w sytuacji, w której znalazł się Inny, nie ma żadnych słów. Milczenie to jest odkryciem, że są doświadczenia, wobec których język staje się bezbronny” (Kot 2012, 109).

Jak wskazują podjęte przeze mnie badania, w kulturze ubóstwa rozmowa i dialog nie są praktykowane także z powodu monotonności i powtarzalności problemów, co wiąże się z przekonaniem, że nie ma o czym rozmawiać. Skutkiem tego jest wycofywanie się z interakcji, co wprawdzie pozwala nie podejmować tematów dotkliwych, ale też pozbawia jednostkę szansy na interakcyjne treningi, które uczyłyby, jak wchodzić w dialog, jak być słuchanym 
i jak słuchać innych. W przypadku dzieci ma to funkcje wykluczające. Bez tych treningów interakcyjnych trudno o odwagę mówienia, bowiem „Mówienie jest wyrazem tego, co usłyszeliśmy z zewnątrz i tego, co poczuliśmy w sobie podczas słuchania. Mówienie jest odpowiedzią na usłyszane" (Grün 2016, 67). Dodatkowo milczeniu i niewchodzeniu w dialog z innymi sprzyjają ograniczenia językowe, które nie pozwalają na zróżnicowany, pogłębiony werbalny przekaz doświadczeń. Wiąże się to również z przekonaniem o tak przytłaczającej skali biedy, że nie sposób jej wyrazić w ubogim słowniku. Choć chodzi tu nie tylko o ubóstwo słów, ponieważ „Ludzkie doświadczenia bywają tak trudne i traumatyczne, że niemożliwe staje się ich werbalizowanie" (Szpunar 2020, 267). Jak wskazuje Jaromir Brejdak, ,,milczenie to aktywny, choć pozawerbalny sposób komunikowania czegoś lub wskazywania na obszar poza możliwą werbalizacją. Milczenie jest cieniem słowa i jako takie stanowi dopełnienie mowy" $(2016,22)$. Przyjęty wymóg przemilczania problemów z czasem rozszerzany jest na inne tematy, co skutkuje uogólnioną obawą przed komunikowaniem. Parafrazując słowa Margaret Archer, to, w jaki sposób ludzie definiują swoje troski i w jakim porządku mówią o doświadczaniu ich, definiuje ich samych $(2013,14)$, ważne jest „określenie tego, w jaki sposób poradzić sobie z afektywnymi komentarzami pochodzącymi z trzech różnych porządków rzeczywistości i odnoszącymi się do trzech rodzajów ludzkich trosk - dobrostanu fizycznego, osiągnięć performatywnych i poczucia własnej wartości” (2013,228). Ludziom w kulturze ubóstwa towarzyszy przekonanie, że to problemy egzystencjalne są najważniejszą, a czasem jedyną treścią funkcjonowania społecznego, a zatem z trudem mogą oni znaleźć tematy pozbawione negatywnej konotacji.

Milczące dzieci wśród ubogich (choć nie tylko), to często synonim grzecznych i posłusznych dzieci, które nie sprawiają dorosłym problemów, niczego nie oczekują, nie wymagają i nie stawiają rodzicom ocen za sytuację życiową w której się znalazły. Takie zachowanie jest dla dorosłych wskaźnikiem ich uprzywilejowanej pozycji, zaznaczenia własnej przewagi i odbierania szacunku, podczas gdy dzieci wybierają milczenie jako wynik postawy rezygnacji, co obrazuje jedna z wypowiedzi: (Lewis 1970, 382-383) „Byłem już duży i wiedziałem, co robię. Ale choć on krzyczał na mnie, nie odpowiadałem, bo co by mi to dało? Owszem, mogłem mu odpowiedzieć więcej, niż on mówił, ale po co? Nie miałoby to celu, więc milczałem. Mama mówiła mi, żebym się nie odzywał, więc nawet gdy byłem zły, nie mogłem odpowiedzieć. Czasem nie mówiłem do niego całymi dniami”.

Milczenie dorosłych wobec dzieci ma odmienne znaczenie, aniżeli ukazywanie podporządkowania czy rezygnacji. Jest ono często jednoznaczne z przekazem niezadowolenia, nieaprobowania dziecka i ma za zadanie tworzenie napięcia, które skłania dziecko do zabiegania o względy rodzica, jest zatem strategią presji. Jak wskazuje jedna z wypowiedzi z analizowanych Pamięt- 
ników: „Moje dzieci boją się, gdy milczę i nie chcę z nimi rozmawiać, wtedy same zaczynają się thumaczyć" (Pamiętniki 1967a, 59).

W życiu ubogich milczenie staje się stałym składnikiem interakcji: łagodzenia konfliktów, obłaskawiania innych i okazywania im podporządkowania. Pozwolenie na to, aby w interakcji mówiła tylko jedna ze stron, daje uznanie jej wyższości. W otaczającym świecie kultury ubóstwa, w którym niewiele się posiada, panuje przekonanie o posiadaniu innych na wyłączną własność, dlatego milczenie dzieci i prawo do mówienia również pozostaje w dyspozycji ich „właściciela”.

Interesujące jest to, że w Pamiętnikach relacje w rodzinie prezentowane są poprzez opisy realnej, ale także wyobrażonej komunikacji wzajemnej rodziców z dziećmi. Skłania to członków rodziny do kreowania w wyobraźni scenariuszy dialogów, jakie można określić mianem potencjalnych, oczekiwanych i traktowanych jako niemożliwe. Takie próby rozmów podejmowane w wyobraźni składają się z projektowanych własnych, wymarzonych odpowiedzi, ma to za zadanie obronę poczucia własnej godności. Obrazuje to wypowiedź: (Lewis 1964, 79) „Nieraz chciałem zagadać do niego: «Powiedz, ojcze, co ja ci takiego zrobiłem? Dlaczego myślisz o nas jak najgorzej? Dlaczego traktujesz nas jak zbrodniarzy? Czy nie widzisz, że bywają synowie, którzy są nałogowcami albo we własnych domach naruszają święte prawa rodziny? Albo nawet mordują ojców?» Jeśli mi starczy śmiałości, to chciałbym mu to kiedyś powiedzieć, oczywiście w uprzejmy sposób. Ale ile razy próbowałem zacząć z ojcem rozmowę, coś mnie powstrzymywało. $Z$ innymi ludźmi słów mi nie brakuje, gdzie tam! A z nim nie: czułem zaraz, że coś mi siedzi w gardle i nie pozwala mówić”.

Zarówno w pracach Lewisa, jak i w Pamiętnikach badani raczej nie podejmują wątków rozmowy ze względu na utarty schemat działania, w którym nie widzi się potrzeby omawiania spraw nawet znaczących, ponieważ znamienne jest przekonanie, że życie powinno być poddane własnemu biegowi.

Milczenie w opisach pamiętnikarskich jest ukrywaniem faktów, co ma na celu ochronę siebie lub innych. Nieinformowanie bliskich o złej sytuacji jest jednak ochroną pozorną, ponieważ wszyscy doświadczający biedy i tak odczuwają jej konsekwencje. Niemożność wymiany przeżyć w dialogu jest zatem w znacznej mierze kolejnym (pozamaterialnym) trudnym doświadczeniem. Nierozmawianie o problemach dotyczy wielu spraw codziennych, jak np. ukrywanie ceny lekarstw, aby chory nie miał poczucia winy i pozwolił na leczenie: (Pamiętniki 2003b, 210) „Rzadko o coś mnie prosi, nawet gdy jest chory nie przyznaje się, żebym nie musiała kupować leków [...] Nie da się wyrazić słowami tego uczucia: ból, żal, rozpacz".

W sytuacjach intencjonalnego milczenia ,dla dobra innych”, milczenie na temat problemów jest zwykle jednoznacznie argumentowane, jednym z wy- 
jaśnień jest przekonanie, że: (Pamiętniki 1967a, 336) „Na złą nowinę jest zawsze czas".

Ukrywanie prawdy powoduje, że komunikacja między rodzicami a dziećmi jest dwuznaczna. Nieporozumienie w relacjach wiąże się także z wykluczającymi się komunikatami, w których przekaz ma inne niż dosłowne znaczenie. Na poziomie werbalnym przekaz wydaje się negatywny, na poziomie emocjonalnym jest wyrażeniem chęci uczynienia dobra. W odniesieniu do małych czy nastoletnich dzieci sprzeczność komunikatów powoduje pseudokomunikację. Odwołuje to do koncepcji określanej w literaturze jako podwójne związanie, „gdy dwa zbiory komunikatów docierających do jednostki są ze sobą na tyle sprzeczne, że uniemożliwiają wybór właściwej reakcji, a przy tym są obwarowane jednakowo nieprzyjemnymi sankcjami. Oznacza to, iż realizacja jednego z wymagań (opisanego przez jeden zbiór informacji) pociąga za sobą sankcje z tytułu nie zrealizowania drugiego (sprzecznego) wymagania. Co więcej, istnieje również sankcja (określony zbiór informacji) uniemożliwiająca bezbolesne opuszczenie sytuacji konfliktotwórczej" (Domachowski 1993, 154-155). Można wskazać, że w kulturze ubóstwa brak komunikowania wprost jest stałym elementem interakcji. Brak komunikacji jest równie szkodliwy jak zła komunikacja (Biała 2011, 457).

\section{Nieumiejętność wyrażania uczuć}

Znamienne w kulturze ubóstwa jest to, że o uczuciach mówi się rzadko. Wśród skrajnie ubogich panuje złudzenie, że skoro problemy są przemilczane, to zapewne nieujawniane są także pozytywne uczucia, co daje dzieciom nadzieję, że nie są dla rodziców obojętne. Najczęściej nie ma to potwierdzenia w zachowaniach rodziców i ich interakcjach z dziećmi, które nacechowane są obojętnością i jedynie deklaratywnym zaangażowaniem dorosłych w problemy dzieci. Takie postawy uznawane są za konieczne, ponieważ uczucia i emocje świadczą jedynie o słabości.

W rodzinach osób skrajnie ubogich dzieci przemilczają lub maskują przed rodzicami własne problemy i ukrywają swoje potrzeby z powodu dbałości o ich samopoczucie. Jest to część odgrywania roli dziecka troszczącego się o dorosłych. Często w interakcjach udają one obojętność na identyfikowane u nich problemy i deficyty, głównie $\mathrm{z}$ powodu niechęci do pogarszania trudnej sytuacji rodziny, wskazuje na to wypowiedź w jednym z pamiętników: (Pamiętniki 2003b, 196-197) „Weronika kupiła zeszyty, ołówki, długopisy, bilet miesięczny.

- Mamo, straciłam prawie 100 zł.

- Nic się nie martw córeczko, jakoś to będzie. 
Pocieszają mnie, bo widzą, że się ciągle zamartwiam. Książek nie dostaną, bo skąd. Nawet używane są strasznie drogie. Oni o tym wiedzą. Mówią: "po co książki? Będziemy robić notatki, czasami pożyczymy i jakoś będzie». Czuję się podle".

W ukrywanie prawdziwych emocji i uczuć zwykle zaangażowane są dwie strony interakcji - zarówno rodzice, jak i dzieci są świadomi podejmowanej gry, jednak dla dobra innych wybierają milczenie, nie ujawniają wiedzy na temat dotkliwej sytuacji życiowej. Nieujawnianie emocji, a także niedopuszczanie do ich wyrażania jest znamienne nie tylko w rodzinach ubogich, ale też w rodzinach określanych jako problemowe. Brak pytania o potrzeby dziecka, przemilczanie i niedopuszczanie do wyrażania uczuć dzieci, to sytuacje znamienne dla członków rodzin doświadczających nie tylko emocjonalnego dystansu, ale również fizycznej rozłąki, na co wskazuje Natasza Doiczman-Łoboda, analizując funkcjonowanie rodzin migracyjnych $(2020,220)$.

W kulturze ubóstwa przyjęte jest, że dzieci są przygotowywane do bycia hardymi, odpornymi na raniące doświadczenia. Niezależnie jednak od wieku dziecka i interpretacji zachowań dorosłych istnieje silne przekonanie, że na uczucia trzeba zasłużyć (Lewis 1964, 122-123). Brak dialogu z dziećmi na temat ważnych spraw, brak okazywania emocji, zachowania przeczące prawdziwym uczuciom, są cechami charakterystycznymi interakcji także w szerszym kontekście rodzinnym. Również dzieci wobec innych tłumią uczucia, zwykle nie wyrażając ich wprost. Ten brak otwartości na dialog okazywany jest wprost i jednoznacznie odbierany przez dzieci jako osobista niechęć do relacji z nimi: ,[...] i nigdy nie pozwalał wyrazić własnego zdania ani jakoś zbliżyć się do siebie. Jeśli go o coś pytaliśmy, odpowiadał:

- Co wy tam wiecie, bałwany? Stulcie pysk. - Zawsze nas potrafił upokorzyć" (Lewis 1964, 78-79).

Znamienne jest to, że jeśli pojawiają się rzadkie przypadki okazywania uczuć, podyktowane są sytuacjami, z których czerpie się wymierne korzyści, jest ono instrumentalne (np. uzyskania od dzieci pieniędzy). W opisach indagowanych podejmowany temat niezaspokojonych potrzeb emocjonalnych jest znaczący dla jednostki. W wielu refleksjach zarówno bohaterów Lewisa, jak i pamiętnikarzy ujawnia się brak świadomości, że w większości przypadków milczenie było skutkiem skupienia się na dbałości o sferę materialną i zaniedbywaniem sfery emocjonalnej. Ciekawy przykład interakcji toczącej się na poziomie pozorów przedstawia dialog: „Ojciec otworzył drzwi - był w bieliźnie. Zobaczyłem na jego twarzy radość, ale na mój widok zaraz się ją postarał ukryć, opanował wzruszenie i stał poważny.

- Więc wróciłeś nareszcie.

- Tak, tata, wróciłem. 
Zdawało mi się, że chce mnie pocałować, ja też miałem straszną ochotę go uścisnąć, ale ponieważ on się trzymał na wodzy więc i ja też - ten sam mur pomiędzy nami, jak zawsze, ot co" (Lewis 1964, 489).

$\mathrm{Z}$ analizy interakcji nie można jednak wysuwać wniosków, że członkowie rodziny są nawzajem sobie obojętni. W przeważającej mierze brak umiejętności porozumienia, a nie niechęć do relacji z innymi, jest głównym powodem milczących „dramatów interakcyjnych”. W wielu przypadkach to właśnie brak porozumienia i skłonność do komunikowania innym tylko negatywnych emocji skutkuje globalną niską oceną dzieci, jakiej dokonują rodzice, i złą oceną rodziców przez dzieci, a w konsekwencji ich niską samooceną.

\section{Milczenie jako odpowiedź na agresję komunikacyjną w kulturze ubóstwa}

W źródłach O. Lewisa zamieszczone są także opisy odwołujące się do ogólnego przedmiotu nieporozumień. W relacjach rodziców z dziećmi pojawia się dodatkowy aspekt sugerujący obraz interakcji, którego interesującą częścią jest sam język, jakim komunikują się jednostki. W opisach indagowanych Lewisa sposób porozumiewania z dziećmi ogólnie można określić jako wulgarny i obcesowy. Analiza języka skłania do refleksji, że również w tym obszarze rozmowa toczy się na dwóch poziomach - jawnym i ukrytym. Przemoc słowna ma charakter inicjujący rozmowę, żartobliwy, staje się rytuałem komunikacyjnym. W sytuacjach trudnych podporządkowanie okazywane milczeniem wobec złego traktowania jest jedyną oczekiwaną reakcją. W przyjętych schematach interakcyjnych konflikty najczęściej ma prawo wzbudzać głowa rodziny, a ich przebieg odbywa się według ugruntowanego wzorca, w którym rodzina wysłuchuje krzyków i obelg w milczeniu: „Kiedy się kłócimy, synowie nie odzywają się, biedacy. Kiedy chcą mnie bronić, on mówi: - Nie wtrącajcie się! Nie wiecie, o co się kłócimy. Moi synkowie, biedaki, milczą. Kiedy ich beszta, ja też się nie wtrącam, bo zaraz się złości. - Nie mieszaj się do tego. Ja jeden tu rozkazuję, a jak będziesz się wtrącać, to dostaniesz" (Lewis 1970, 437).

W sytuacjach konfliktu dzieci są zwykle pouczane, jak okazywać podporządkowanie, co ujawnia m.in. przestroga, aby w przypadku krzyków milczeć i nie patrzeć w oczy ojcu, by nie eskalować przemocy.

$\mathrm{W}$ wypowiedziach badanych widać, że wulgarne przezywanie jest stałym elementem porozumienia, a mówiący nie mają świadomości niestosowności epitetów, nie odbierają ich też jako obraźliwych. W wielu takich interakcjach odnaleźć można sprzeczność - skrajnie negatywne określenia są przejawem sympatii, decyduje o tym nie ich treść, ale sposób wypowiadania komunikatu i jego kontekst. Okrucieństwo komunikatów nie jest odnoszone przez dzieci 
do treści komunikatu, a raczej do przyczyny. To nie obelg się one obawiają, deklarują lęk przed zachowaniem rodzica.

W przekazach indagowanych Lewisa widać wyraźnie, że poprzez wulgarne i przemocowe słownictwo rodzice demonstrują wobec dzieci przewagę komunikacyjną. Dzieci (zwłaszcza małe) nie mają szansy dorównać tym nietypowym przenośniom, cynicznym uwagom. $Z$ tego powodu komunikowanie wulgarne jest jednostronne, a jedyną aprobowaną reakcją na przewagę mówiącego jest milczenie, co ma też reperkusje w zachęcaniu do fizycznej przemocy i obojętności wobec niej, obrazuje to wypowiedź: „,- Jeżeli któryś z was zostanie zabity, dajcie mi znać. Wezmę łopatę i zgarnę jego resztki z podłogi” (Lewis 1976a, 416).

Cynizm wobec dzieci jest niezależny od tego, czy ich zachowanie ukazuje ich lekkomyślność i przewinienia, czy też zaabsorbowanie problemami rodziny, jak na przykład brakiem jedzenia. Agresywne komunikaty zwrotne mogą pojawić się niespodziewanie, również w sytuacji ujawnianej przez dzieci troski:

„-- Co my będziemy mieli do jedzenia wieczorem? - zapytał.

- Ciebie i twoją wielką jadaczkę, oto co - odpowiedziała Felícita" (Lewis 1976a, 426).

Wskazań takich jest w tekście wiele, zwykle ukazują one skrajność emocji, jak np.: „Czasami chęć mnie bierze pozabijać te dzieci i samą siebie podpalić. [...] Pewnego dnia chwyciłam za nóż i chciałam przebić nim Angelita" (Lewis 1976b, 54).

Przekazywanie negatywnych emocji, jakie jest przedmiotem wielu opisów bohaterów Lewisa, odbywa się w sposób nieprzewidywalny. Nie ma w danej sytuacji bodźca, który mógłby być bezpośrednio wiązany z agresją. Zarówno pozytywne, jak i negatywne zachowanie dzieci może wywołać werbalną agresję i w następstwie przemoc fizyczną. W sytuacjach problemowych dzieci przejawiają zachowania potwierdzające wycofanie i ukazujące taką postawę dorosłym. Dzieci w relacjach z dorosłymi przygotowywane są do unikania interakcji i przyjęcia milczenia jako jedynej możliwej odpowiedzi: „,- Wystarczy mi spojrzeć, jak te gówniarze żrą, a zaraz mnie aż ściska, [...]. Niceśmy złego nie zrobili, a on się tak do nas odezwał. Od tej pory nigdy nie siadałem do stołu razem z ojcem" (Lewis 1964, 71-72). Takie zachowania, nawet jeśli są tolerowane w teraźniejszości, mają swoje reperkusje w przyszłości, w późniejszych relacjach z innymi.

Również w agresji słownej nie brak kierowanych do dzieci sprzecznych komunikatów. Zwracanie się do dzieci z łagodnością nie przeszkadza oznajmiać karzących decyzji. Obrazuje to fragment wypowiedzi ojca do córki, który nie jest tylko aktem werbalnym, ale także symbolicznie porządkuje zachowania. Wyrzucenie dziecka z domu jest powodowane chęcią pozbycia się z własnego życia osoby, którą trzeba wspierać. Cytat poniżej ukazuje pewien 
schemat interakcyjny, obecny w wielu relacjach, który można zawrzeć w cyklu: prośba - spełnienie prośby lub jej niespełnienie - agresja proszącego niezależna od reakcji na komunikat:

„-- Słuchaj, córeczko, chcę, żebyś coś dla mnie zrobiła.

- Naturalnie, tato.

- Zgarnij swoje łachy i idź ... idź sobie stąd, wynoś się!

- Idź do męża.

- Dobrze, pójdę. Lepiej mi przy nim niż przy ojcu.

- No to idź. Ale ostrzegam cię, że od dzisiejszego dnia nie przestąpisz mego progu, a ja nie przestąpię twojego. Nigdy. Możesz uważać, żeś mnie pochowała, i ja zrobię to samo" (Lewis 1970, 424-425).

$\mathrm{W}$ przekazach bohaterów Lewisa widać, że między najbliższymi w rodzinie obecne są ciągłe złorzeczenia, nawet jeśli relacje między nimi nie są skonfliktowane. Są to wypowiadane zdania przy okazji codziennych rozmów, mające wyrazić niezadowolenie, ale także podkreślić wszechobecny wpływ innych na życie jednostki. Są to wyrażenia podkreślające niechęć do danej osoby, ale także zdania przepowiadające przyszłość, zawierające groźby o przewidywanym cierpieniu, jedno z nich wypowiadane przez ojca do syna brzmi: ,Źle ci będzie w życiu, i gdzie pójdziesz, to drzwi ci zamkną przed nosem" (Lewis 1964, 98) ${ }^{1}$.

Wyrażanie negatywnych emocji wobec dzieci i ich milczenie zaprzecza deklarowanym w opisach uczuciom. Zachowania wobec dzieci pokazują instrumentalne traktowanie. Niespełnianie oczekiwań, które są kierowane do dzieci, powoduje konflikty, a nawet trwałe lub czasowe zerwanie kontaktów (w przypadku małych dzieci może to być ich porzucanie, w najlepszym przypadku długotrwałe milczenie wobec nich ukazujące ich ignorowanie). Paradoksalnie jednak, mimo negatywnych skutków separacji od bliskich, ujawniana jest ona w wielu przekazach jako szczególnie oczekiwana przez obie strony interakcji. Separacja zarówno fizyczna, jak i symboliczna jest bowiem iluzoryczną zapowiedzią spokoju.

\section{Podsumowanie}

Milczenie może być charakteryzowane jako pożądany składnik społecznych interakcji, ale także jako negatywna postawa interakcyjna. W pozytywnym ,użyciu” milczenie jest wynikiem wyboru jednostki, która w sposób

\footnotetext{
${ }^{1}$ Nie stanowi to o wyjątkowości zachowań indagowanych, wskazuję ten aspekt jedynie w perspektywie interakcji. Złorzeczenie, klątwa, rozumiana jako rytuał słowny obecne jest w większości kultur, w literaturze wskazywane jako zjawisko uniwersalne. Zob. Anna Engelking, Klątwa. Rzecz o ludowej magii stowa, ON, Warszawa 2010, s. 17.
} 
względnie świadomy (niekoniecznie racjonalny) przyjmuje nieuczestniczenie w wymianie informacji, dialogu, rozmowie. W negatywnym kontekście milczenie jest wynikiem presji, przymusu i staje się przyczynkiem do oczekiwania jak najmniej dotkliwych interakcji. W złożonych procesach interakcyjnych podejmowane jest ono jako strategia obronna, uruchamiana w sytuacji nierównoważnej relacji, w której jedna strona jest w gorszym położeniu, podporządkowaniu, uległości.

Milczenie można potraktować jako postawę powstrzymania się od mówienia, po to żeby usłyszeć innych, ponieważ to w milczeniu możliwe jest odbieranie sensu usłyszanych słów. Może też być ono podejmowane w celu bycia zauważonym (usłyszanym). Takie milczenie jest nakierowane na Innego, a jego intencjonalność ma doprowadzić do antycypowanych, pozytywnych skutków. Milczenie w relacjach z innymi jest daniem sobie i innym czasu na przetworzenie informacji, zebranie myśli, uporządkowanie znaczeń (Miller i Rollnick 2014, 349-350).

Odmienne od tego ujęcia jest milczenie, będące wynikiem przymusowego wykluczenia z rozmowy, dialogu, wymiany informacji. Wówczas jest ono konsekwencją działania przeciw Innemu, wbrew jego woli pozbawia go podmiotowości, możliwości zakomunikowania swojej perspektywy doświadczeń. Tak zarysowany problem zgody na milczenie jako wymuszonej strategii obronnej jest przedmiotem podjętej w artykule analizy.

Badania wskazują, że ludzi w skrajnym ubóstwie charakteryzuje wykluczający sposób komunikowania się, niepozwalający na wypowiadanie się jednej ze stron dyskursu i podporządkowujący tych, którzy są klasyfikowani jako słabsi. Ma to na celu demonstrowanie własnej przewagi, ale także stanowi obronę siebie przed problemami, które wyartykułowane wzmacniałyby poczucie negatywnego położenia społecznego. Milczenie w takim przypadku jest powodowane chęcią ucieczki od problemów, rzadziej wiąże się z przyjętą strategią ochrony innych przed ukrywanymi problemami.

Wyniki analizy wskazują, że milczenie ludzi skrajnie ubogich stanowi trwały element socjalizacji. W przypadku dzieci jest oznaką siły charakteru w znoszeniu porażek, staje się wskaźnikiem biernego poddawania się presji innych, nieabsorbowania innych własnymi sprawami. W rodzinach doświadczających ubóstwa milczące dziecko to dziecko bez problemów, natomiast dziecko, które artykułuje problemy, nie jest odbierane jako dziecko z problemami, a staje się dzieckiem problemowym. Konsekwencją socjalizowanego od dzieciństwa milczenia w relacjach społecznych jest nieumiejętność wchodzenia $\mathrm{w}$ dialog $\mathrm{z}$ innymi. W przypadku ubogich jest to dodatkowo wynik ograniczonych relacji z otoczeniem społecznym, co jest równoznaczne z pozbawieniem się szans na społeczne treningi interakcyjne. Ma to konsekwencje w trwałych deficytach umiejętności wyrażania m.in. poglądów, opinii, potrzeb, 
uczuć. Sprzyja to podejmowaniu w dorosłości przemocowych interakcji, które traktowane są jako stały, aprobowany rytuał nadużyć.

\title{
SILENCE AS A COMMUNICATION STRATEGY OF PEOPLE IN THE CULTURE OF POVERTY
}

\begin{abstract}
SUMMARY
The article presents the results of research on the way of communication in the culture of poverty, which are included in the statements of extremely poor people, which characterize everyday interactions with others. The analyzed communication processes are limited to interactions within the family. The main sources of the analysis presented in this article are the works of O. Lewis, which constitute the theoretical basis for the concept of the culture of poverty proposed by the author, as well as Diaries of the Unemployed, the publication of which in the 1930s and 2003-2006 was a response to the written diary competitions. The aim of this article is to show similar methods of interaction and communication that are characterized by social isolation in the culture of poverty. It is manifested by abandoning communication and choosing silence strategies in relations with others. One of the issues of the article is the description of discourse, making attempts to communicate with those who present an advantage over the weaker people who are in the position of subjection.
\end{abstract}

Keywords: Culture of poverty, communication, verbal aggression, dialogue, silence, muteness.

Slowa kluczowe: kultura ubóstwa, komunikacja, agresja werbalna, dialog, milczenie

\section{BIBLIOGRAFIA}

Archer, Margaret. 2013. Człowieczeństwo. Problem sprawstwa. Kraków: NOMOS.

Biała, Jolanta. 2011. Społeczno-kulturowe uwarunkowania i możliwości rozwiązywania konfliktów pomiędzy rodzicami i dziećmi. W: Wartość i dobro rodziny, red. Jarosław Jęczeń i Marian Stepulak, 455-465. Lublin: KUL.

Brejdak, Jaromir. 2016. Logos komunikującego milczenia. Ethos 1 (113), 21-35.

Charmaz, Kathy. 2009. Teoria ugruntowana w XXI wieku. Zastosowanie w rozwoju badań nad sprawiedliwością społeczną. W: Metody badań jakościowych, t. 1, red. Norman Denzin i Yvonna Lincoln. Redakcja naukowa wydania polskiego: Krzysztof Podemski. Warszawa: PWN.

Domachowski, Waldemar. 1993. Komunikowanie się normalne i zaburzone - wybrane koncepcje. W: Społeczna psychologia kliniczna, red. Helena Sęk, 154-155. Warszawa: PWN.

Doiczman-Łoboda, Natasza. 2020. Problem ,eurosieroctwa” w opinii ekspertów kierujących pomoc do rodzin migrantów zarobkowych. Praca socjalna i wsparcie psychologiczne w do- 
świadczeniach rozłąki migracyjnej. Teologia i Moralnośćc, 15, 2(28).213-225. doi: 10.14746/ tim.2020.28.2.12.

Engelking, Anna. 2010. Klatwa. Rzecz o ludowej magii stowa. Warszawa: ON.

Glaser, Barney i Anselm Strauss. 2009. Odkrywanie teorii ugruntowanej. Kraków: NOMOS.

Grün, Anselm. 2016. Waga stów - siła milczenia czyli nowa kultura rozmowy. Poznań: W drodze.

Handke, Kwiryna. 2008. Socjologia języka. Warszawa: PWN.

Konecki, Krzysztof. 2000. Studia z metodologii badań jakościowych. Teoria ugruntowana. Warszawa: PWN.

Kot, Dobrosław. 2012. Granice mowy. Ethos, 1-2 (97-98), 107-120.

Korwin-Piotrowska, Dorota. 2016. Milczenie i nie-milczenie współczesności. Ethos, 1 (113), 124-143.

Lewis, Oscar. 1964. Sanchez i jego dzieci. Autobiografia rodziny meksykańskiej. Warszawa: PIW.

Lewis, Oscar. 1970. Rodzina Martinezów. Życie meksykańskiego chłopa. Warszawa: PIW.

Lewis, Oscar. 1976a. Nagie życie, t. 1. Warszawa: PIW.

Lewis, Oscar. 1976b. Nagie życie, t. 2. Warszawa: PIW.

Lewis, Oscar. 2011a. Dzieci Sancheza. Autobiografia rodziny meksykańskiej. Kraków: BONA.

Lewis, Oscar. 2011b. The Children of Sanchez. Autobiography of a Mexican Family. New York: Vintage Books, Random House.

Macario, Lorenzo i Maria Rocchi. 2011. Komunikacja $w$ relacjach niesienia pomocy. Kraków: WAM.

Maj, Janusz. 2009. Wezwanie mowy. Myślenie mowy, liturgia i piękno w filozofii Franza Rosenzweiga. Kraków: NOMOS.

Miller, William i Stephen Rollnick. 2014. Dialog motywujący. Jak pomóc ludziom w zmianie. Kraków: WUJ.

Osika, Grażyna. 2016. Milczenie jako ucieleśniona praktyka tożsamościowa. Ethos, 1 (113), 36-46.

Oliwa-Ciesielska, Monika. 2013. W poszukiwaniu kultury ubóstwa. Poznań: Wydawnictwo UAM.

Pacławska, Ewa. 2010. Opozycja mówić-milczeć w języku polskim. W: Cisza i milczenie. Społeczno-kulturowe mechanizmy kreowania emocji, red. Bożena Płonka-Syroka i Kaja Marchel, 33-38. Wrocław: Oficyna Wydawnicza Arboretum.

Pamiętniki bezrobotnych. 1967a. Tom 1. (Reedycja publikacji Instytutu Gospodarstwa Społecznego z 1933 roku). Warszawa: PWE.

Pamiętniki bezrobotnych. Pamiętnikarze po latach. Pamiętniki w świetle prasy. 1967b. Tom 2. Warszawa: PWE.

Pamiętniki bezrobotnych. 2003a. Tom 1. Warszawa: SGH IGS.

Pamiętniki bezrobotnych. 2003b. Tom 2. Warszawa: SGH IGS.

Pamiętniki bezrobotnych. 2005a. Tom 3. Warszawa: SGH IGS.

Pamiętniki bezrobotnych. 2005b. Tom 4.Warszawa: SGH IGS.

Pamiętniki bezrobotnych. Materiaty konkursowe. 2006. Tom 5. Warszawa: SGH IGS.

Rapley, Tim. 2010. Analiza konwersacji, dyskursu i dokumentów. Warszawa: PWN.

Silvermann, David. 2008. Prowadzenie badań jakościowych. Warszawa: PWN.

Szpunar, Magdalena. 2020. Rozmawianie bez rozmowy. Ethos, (129), 257-271.

Wittgenstein, Ludwig. 1997. Tractatus logico-philosophicus, thum. Bogusław Wolniewicz. Warszawa: PWN.

Zatorski, Włodzimierz. 2012. Milczeć aby usłyszeć. Kraków: Tyniec.

Monika Oliwa-Ciesielska - profesor UAM, doktor habilitowany nauk społecznych w dyscyplinie socjologia, pracuje w Zakładzie Badań Problemów Społecznych i Pracy Socjalnej w Instytucie Socjologii Uniwersytetu im. Adama Mickiewicza w Poznaniu. Ukończyła studia na kierunkach praca socjalna oraz socjologia. Zajmuje się problematyką wykluczenia społecznego. Laureatka Nagro- 
dy im. Stanisława Ossowskiego za książkę Piętno nieprzypisania. Studium o wyizolowaniu społecznym bezdomnych, a także Nagrody Prezesa Rady Ministrów za książkę $W$ poszukiwaniu kultury ubóstwa. Jest autorką artykułów dotyczących problemu ubóstwa, kultury ubóstwa, bezdomności, mieszkalnictwa socjalnego, wykluczenia społecznego, pomocy społecznej i pracy socjalnej. 